\title{
Identification and Characterization of Ceratocystis fimbriata Causing Lethal Wilt on the Lansium Tree in Indonesia
}

\author{
Suwandi Suwandi (i) *, Chandra Irsan, Harman Hamidson, Abu Umayah, and Khoirotun Dwi Asriyani \\ Department of Plant Protection, Faculty of Agriculture, Sriwijaya University, Palembang 30662, Indonesia \\ (Received on August 5, 2020; Revised on January 25, 2021; Accepted on January 25, 2021)
}

Bark canker, wood discoloration, and wilting of the duku tree (Lansium domesticum) along the watershed of Komering River, South Sumatra Province, Indonesia first appeared in 2013. The incidence of tree mortality was $100 \%$ within 3 years in badly infected orchards. A Ceratocystis species was consistently isolated from the diseased tissue and identified by morphological and sequence analyses of the internal transcribed spacer (ITS) and $\beta$-tubulin regions. Pathogenicity tests were conducted and Koch's postulates were confirmed. The fungus was also pathogenic on Acacia mangium, but was less pathogenic on mango. Partial flooding was unfavourable for disease development. Two described isolates (WRC and WBC) had minor variation in morphology and DNA sequences, but the former exhibited a more pathogenic on both duku and acacia. The ITS phylogenies grouped the most pathogenic isolate (WRC) causing wilting of the duku tree within the aggressive and widely distributed ITS5 haplotype of $C$. fimbriata.

Keywords : Acacia mangium, Ceratocystis canker and wilt, Ceratocystis fimbriata, Lansium tree

Handling Editor : Ki Woo Kim

\footnotetext{
*Corresponding author.

Phone, FAX) +62-711-580059

E-mail)suwandi@fp.unsri.ac.id

ORCID

Suwandi Suwandi

https://orcid.org/0000-0003-3096-5797

(c) This is an Open Access article distributed under the terms of the Creative Commons Attribution Non-Commercial License (http:// creativecommons.org/licenses/by-nc/4.0) which permits unrestricted noncommercial use, distribution, and reproduction in any medium, provided the original work is properly cited.
}

Articles can be freely viewed online at www.ppjonline.org.
The duku (Lansium domesticum Corr.), also known as the langsat and the kokosan is a tropical lowland fruit tree native to western Southeast Asia, from Borneo in the east (Indonesia) to peninsular Thailand in the west. It occurs wild and cultivated in its native countries and is one of the most widely cultivated fruits (Techavuthiporn, 2018; Yaacob and Bamroongrugsa, 1991). Duku is among the most popular local fruits in Indonesia. In 2017, the total number of harvested duku trees in Indonesia was 2.4 million trees, with a total yield of 138.4 metric tons (Badan Pusat Statistik-Statistics Indonesia, 2018). The most famous cultivars are grown in South Sumatra (duku Palembang and duku Komering) due to their sweet flavour combined with a subacid taste and having few seeds, or even being seedless. In South Sumatra, duku is mainly grown as a backyard or garden tree in combination with other native fruit trees along the watershed of the Musi, Komering, Ogan, Lematang, and Rawas rivers.

Lethal disease has rarely been evident on duku trees growing in the wild or cultivated orchard areas. Anthracnose caused by Colletotrichum gloeosporioides, appearing as brownish spots on the fruit bunch and often resulting in premature fruit drop and post-harvest losses, is commonly evidenced throughout the tropics (Yaacob and Bamroongrugsa, 1991). Corky bark disease, which makes the bark become rough and corky and flake off, often resulting in little to no fruit production has been reported on dukus in tropical USA (Keith et al., 2013; Whitman, 1980). In Hawaii, a corky bark canker is associated with an Ascomycete fungus, Dolabra nepheliae, and insect larvae of Araecerus sp. (Coleoptera: Anthribidae) and Corticeus sp. (Coleoptera: Tenebrionidae) feeding under the loosened bark (Keith et al., 2013).

During early January 2014, massive mortality of duku trees along the watershed of the Komering River in Ogan Komering Ulu (OKU) District was reported by most local and some national newspapers. In total, more than 2,000 
trees of the most popular cultivar, duku Komering, died. The symptoms first appeared during the early rainy season of October 2013. Most of the trees that died were predisposed due to partial flooding to a depth of about $20 \mathrm{~cm}$ for about one month from the end of December 2013 to January 2014. However, some affected trees were found growing on non-flooded sites, indicating an infectious disease. In this study, we describe a new bark canker and wilting associated with massive mortality of duku trees in Indonesia, illustrate morphological and molecular-based identification of the pathogen, and describe the pathogenicity of the causal fungus on duku trees and other hosts. Disease progress and spread for 5 years is also discussed.

\section{Materials and Methods}

Disease incidence and isolation of the causal agent. Incidence of diseased trees was assessed in 2014 and 2017 at eight duku orchards in OKU District of South Sumatra. In each orchard, five $10 \times 10 \mathrm{~m}$ plots starting from the centre of the diseased trees were selected. The trees were recorded as infected if any part of the shoot or stem showed disease symptoms. Twenty diseased duku trees were randomly selected from the affected orchards. Sections of the discolored wood from the stem were cut, wrapped in a paper towel and transported to the laboratory for examination. Isolation of the fungal pathogen was performed from discolored wood that had been surface-sterilized with $70 \%$ ethanol for $30 \mathrm{~s}$ and $1 \% \mathrm{NaOCl}$ for $2 \mathrm{~min}$. Small sections (5 $\times 5 \mathrm{~mm}$ ) from the margin of discoloration were placed on a malt extract agar (MEA) amended with $50 \mu \mathrm{g} / \mathrm{ml}$ streptomycin in Petri dishes. Another subset of surface-sterilized wood sections was wrapped between carrot slices to bait for Ceratocystis spp. (Brito et al., 2019; Moller and DeVay, 1968). Baiting was also performed by inserting diseased tissue into freshly harvested cacao pods and cucumber fruit in an attempt to isolate Phytophthora.

Initial identification and cultural characteristics. Initial identification was performed based on morphological characteristics of teleomorphs and anamorphs. Isolates were characterized from 2-week-old cultures grown on $2 \%$ MEA. One hundred measurements of each teleomorph and anamorph structure from each representative isolate were made with an Olympus microscope and an OptiLab camera system (Yogyakarta, Indonesia). The average (mean) and standard deviation (SD) of measurements were computed and presented as mean $\pm \mathrm{SD}$. Morphological characteristics were compared with Ceratocystis isolates from A. mangium (Tarigan et al., 2011) and sweet potato (Engelbrecht and Harrington, 2005).

DNA isolation, PCR, and sequence analyses. Two representative isolates (WRC and $\mathrm{WBC}$ ), isolated from the diseased duku trees were further used for DNA sequence analysis. DNA was isolated from mycelia cultured at $27^{\circ} \mathrm{C}$ for 7 days in malt extract broth (Difco Laboratories, Sparks, MD, USA) in plastic Petri dishes. Total DNA was extracted using bead-beating technology (MO BIO Laboratories, Carlsbad, CA, USA) and the silica spin filter method (Geneaid, Taipei, Taiwan) according to the manufacturer's instructions. DNA concentration and purity were measured spectrophotometrically. The ITS1/5.8 S rDNA/ITS2 (internal transcribed spacer, ITS) region of Ceratocystis isolates was amplified by PCR, using ITS 1 (forward: 5'-TCCGTAGGTGAACCTGCGG-3') and ITS4 (reverse: $5^{\prime}$-TCCTCCGCTTATTGATATGC-3') (White et al., 1990). The $\beta$-tubulin gene (TUB) region was amplified by PCR, using $\beta$ tla (forward: 5'-TTCCCCCGTCTCCACTTCTTCATG-3') and $\beta \mathrm{t} 1 \mathrm{~b}$ (5'-GACGAGATCGTTCATGTTGAACTC-3') (Glass and Donaldson, 1995). PCR reaction mixtures consisted of $1 \mu$ of each primer $(10$ $\mathrm{mM}$ ), $15 \mu \mathrm{l}$ of REDiant $2 \times$ PCR Master Mix (1st BASE, The Gemini, Singapore), $3 \mu$ of DNA template (2-10 ng) and $10 \mu \mathrm{l}$ nuclease-free water to make up $30 \mu \mathrm{l}$ total volume reactions. PCR was performed using Thermal Cycler (SureCycler 8800, Agilent, Santa Clara, CA, USA) with a 5 -min $95^{\circ} \mathrm{C}$ denaturation step followed by 35 cycles of 30 $\mathrm{s}$ denaturation at $95^{\circ} \mathrm{C}, 30 \mathrm{~s}$ annealing at $56^{\circ} \mathrm{C}$ for ITS and $55^{\circ} \mathrm{C}$ for $T U B$, and $40 \mathrm{~s}$ extension at $72^{\circ} \mathrm{C}$, followed by a final extension of $5 \mathrm{~min}$ at $72^{\circ} \mathrm{C}$. Negative controls (without template DNA) were applied in each assay. The PCR products of ITS and TUB regions were sequenced at 1st BASE, Co., Ltd. (Kuala Lumpur, Malaysia).

Identification of isolates was accomplished by BLAST searches of the ITS and TUB sequences on the GenBank database (http://www.ncbi.nlm.nih.gov). BLAST identification suggested that both isolates belonged to the species Ceratocystis fimbriata. Phylogenetic analyses were performed to identify the species of Ceratocystis most closely related to the Lansium isolate from Indonesia. $\beta$-tubulin datasets were generated using ex-type and ex-paratype sequences representing species in the Latin American (LAC) and Asian clade of the $C$. fimbriata species complex (Barnes et al., 2018; Fourie et al., 2015; Oliveira et al., 2015). The $\beta$-tubulin sequences (Table 1) were aligned using the online software MAFFTv.7 (Katoh et al., 2019) with the best alignment strategy was automatically selected by the software. Sequence alignments were manually edited in MEGA X (Kumar et al., 2018). There were 34 aligned 
Table 1. Collection details and GenBank accession number of ITS and $\beta$-tubulin sequence for isolates of Ceratocystis fimbriata included in this study

\begin{tabular}{|c|c|c|c|c|c|c|}
\hline \multirow{2}{*}{ Isolate } & \multicolumn{2}{|c|}{ GenBank accession no. } & \multirow{2}{*}{$\begin{array}{l}\text { Species and } \\
\text { ITS haplotype }\end{array}$} & \multirow{2}{*}{ Host } & \multirow{2}{*}{ Origin } & \multirow{2}{*}{ Reference } \\
\hline & ITS & $\beta$-Tubulin & & & & \\
\hline C1418 & AY157956 & - & C. fimbriata TS1a & Ipomoea batatas & USA & Harrington et al. (2014) \\
\hline C1857 & HQ157542 & - & C. fimbriata ITS1 & Ficus carica & Brazil & Harrington et al. (2014) \\
\hline CMW4797 & FJ236733 & - & C. fimbriata ITS1b & Eucalyptus sp. & Congo & Harrington et al. (2014) \\
\hline CMW9998 & FJ236721 & - & C. fimbriata ITSb & Eucalyptus sp. & South Africa & Harrington et al. (2014) \\
\hline $\mathrm{C} 1655$ & HQ157546 & - & C. fimbriata ITS2 & Mangifera indica & Brazil & Harrington et al. (2014) \\
\hline $\mathrm{C} 1440$ & HQ157544 & - & C. fimbriata ITS3 & Eucalyptus sp. & Brazil & Harrington et al. (2014) \\
\hline CMW5328 & AF395686 & - & C. fimbriata ITS3 & E. grandis & Uganda & Harrington et al. (2014) \\
\hline $\mathrm{C} 1442$ & HQ157545 & - & C. fimbriata ITS4 & Eucalyptus sp. & Brazil & Harrington et al. (2014) \\
\hline CMW38737 & KF878326 & KF878335 & C. fimbriata ITS5 & E. grandis & Zimbabwe & Jimu et al. (2015) \\
\hline $\mathrm{C} 1345$ & AY157966 & - & C. fimbriata ITS5 & Eucalyptus sp. & Brazil & Harrington et al. (2014) \\
\hline A59662 & KF650948 & - & C. fimbriata ITS5 & Camellia sinensis & China & Xu et al. (2019) \\
\hline YM061 & AM712445 & - & C. fimbriata ITS5 & Colocasia esculenta & China & Li et al. (2016) \\
\hline P20053 & AM292204 & - & C. fimbriata ITS5 & Punica granatum & China & Li et al. (2016) \\
\hline $\mathrm{C} 1$ & MF033455 & MF040712 & C. fimbriata ITS5 & Acacia sp. & Vietnam & Trang et al. (2018) \\
\hline CMW22563 & EU588656 & EU588636 & C. fimbriata ITS5 & A. mangium & Indonesia & Tarigan et al. (2011) \\
\hline WRC & MT229127 & MW013766 & C. fimbriata ITS5 & Lansium domesticum & Indonesia & Present study \\
\hline C2055 & HQ157548 & - & C. fimbriata ITS6 & Mangifera sp. & Brazil & Harrington et al. (2014) \\
\hline CMW13582 & KC261853 & - & C. fimbriata ITS6z & Hypocryphalus mangifera & Oman & Naidoo et al. (2013) \\
\hline WBC & MT229128 & MW013767 & C. fimbriata ITS6z & L. domesticum & Indonesia & Present study \\
\hline CMW13851 & AY953383 & EF433308 & C. fimbriata ITS7b & M. indica & Oman & Van Wyk et al. (2005) \\
\hline CMW23634 & EF433302 & EF433311 & C. fimbriata ITS7b & M. indica & Pakistan & Van Wyk et al. (2007) \\
\hline CMW22579 & EU588658 & - & C. fimbriata ITS7b & A. mangium & Indonesia & Tarigan et al. (2011) \\
\hline CMW8856 & AY233867 & - & C. fimbriata ITS8a & Citrus sp. & Colombia & Harrington et al. (2014) \\
\hline CMW17808 & EF127990 & - & C. fimbriata ITS8c & Eucalyptus sp. & Colombia & Harrington et al. (2014) \\
\hline CMW22092 & FJ151432 & - & C. fimbriata ITS8e & E. deglupta & Ecuador & Harrington et al. (2014) \\
\hline C1558 & AY157965 & - & C. fimbriata ITS9 & M. indica & Brazil & Harrington et al. (2014) \\
\hline C1914 & HQ157540 & - & C. fimbriata ITS9 & C. esculenta & Brazil & Harrington et al. (2014) \\
\hline C994 & AY157964 & - & C. fimbriata ITS10 & M. indica & Brazil & Harrington et al. (2014) \\
\hline $\mathrm{Cf} 4$ & EF042605 & - & C. fimbriata ITS10a & M. indica & Brazil & Harrington et al. (2014) \\
\hline $\mathrm{C} 1865$ & AY526286 & - & C. fimbriata ITS11 & C. esculenta & Brazil & Harrington et al. (2014) \\
\hline C1926 & HQ157541 & - & C. fimbriata ITS12 & C. esculenta & Brazil & Harrington et al. (2014) \\
\hline $\mathrm{C} 1688$ & AY526291 & - & C. fimbriata ITS14 & M. indica & Brazil & Harrington et al. (2014) \\
\hline C925 & AY157967 & - & C. fimbriata ITS15 & Gmelina arborea & Brazil & Harrington et al. (2014) \\
\hline C924 & HQ157539 & - & C. fimbriata ITS16 & G. arborea & Brazil & Harrington et al. (2014) \\
\hline CMW6569 & - & DQ371652 & C. pirilliformis & E. nitens & Australia & Barnes et al. (2018) \\
\hline CMW6579 & - & DQ371653 & C. pirilliformis & E. nitens & Australia & Barnes et al. (2018) \\
\hline CMW17808 & - & EU881898 & C. neglecta & E. grandis & Colombia & Fourie et al. (2015) \\
\hline CMW18194 & - & EU881899 & C. neglecta & E. grandis & Colombia & Fourie et al. (2015) \\
\hline CMW5751 & - & AY177225 & C. colombiana & Coffea arabica & Colombia & Fourie et al. (2015) \\
\hline CMW5761 & - & AY177224 & C. colombiana & C. arabica & Colombia & Fourie et al. (2015) \\
\hline CMW14803 & - & KJ631108 & C. cacaofunesta & Theobroma cacao & Ecuador & Fourie et al. (2015) \\
\hline CMW15051 & - & KJ601510 & C. cacaofunesta & T. cacao & Costa Rica & Fourie et al. (2015) \\
\hline CMW8850 & - & AY233875 & C. papillata & Citrus $\times$ Tangelo hybrid & Colombia & Van Wyk et al. (2010) \\
\hline CMW8856 & - & AY233874 & C. papillata & Citrus limon & Colombia & Van Wyk et al. (2010) \\
\hline CMW14797 & - & EF433307 & C. fimbriata & M. indica & Brazil & Barnes et al. (2018) \\
\hline CMW28907 & - & FJ200270 & C. fimbriata & M. indica & Brazil & Barnes et al. (2018) \\
\hline
\end{tabular}


Table 1. Continued

\begin{tabular}{|c|c|c|c|c|c|c|}
\hline \multirow{2}{*}{ Isolate } & \multicolumn{2}{|c|}{ GenBank accession no. } & \multirow{2}{*}{$\begin{array}{l}\text { Species and } \\
\text { ITS haplotype }\end{array}$} & \multirow{2}{*}{ Host } & \multirow{2}{*}{ Origin } & \multirow{2}{*}{ Reference } \\
\hline & ITS & $\beta$-Tubulin & & & & \\
\hline CMW1547 & - & EF070443 & C. fimbriata & I. batatas & Papua New Guinea & Barnes et al. (2018) \\
\hline C1421 & - & KF302689 & C. fimbriata & I. batatas & USA & Barnes et al. (2018) \\
\hline CMW24174 & - & EF190951 & C. fimbriatomima & Eucalyptus hybrid & Venezuela & Fourie et al. (2015) \\
\hline CMW24176 & - & EF190952 & C. fimbriatomima & Eucalyptus hybrid & Venezuela & Fourie et al. (2015) \\
\hline CMW21127 & - & EU588643 & C. fimbriata & A. crassicarpa & Indonesia & Oliveira et al. (2015) \\
\hline CMW24664 & - & JQ862720 & C. fimbriata & Eucalyptus hybrid & China & Chen et al. (2013) \\
\hline CBS115173 & - & KF302700 & C. fimbriata & Gmelina arborea & Brazil & Luchi et al. (2013) \\
\hline CBS14653 & - & KF302702 & C. fimbriata & C. arabica & Suriname & Luchi et al. (2013) \\
\hline CMW14802 & - & EF070425 & C. platani & Platanus occidentalis & USA & Barnes et al. (2018) \\
\hline CMW23450 & - & KJ601513 & C. platani & P. occidentalis & Greece & Barnes et al. (2018) \\
\hline CMW11424 & - & AY528966 & C. polychroma & Syzygium aromaticum & Indonesia & Barnes et al. (2018) \\
\hline CMW11436 & - & AY528967 & C. polychroma & S. aromaticum & Indonesia & Barnes et al. (2018) \\
\hline CMW19383 & - & EF070430 & C. atrox & E. grandis & Australia & Barnes et al. (2018) \\
\hline CMW19385 & - & EF070431 & C. atrox & E. grandis & Australia & Barnes et al. (2018) \\
\hline
\end{tabular}

datasets (Supplementary Fig. 1) and the sequences were used for phylogenetic tree construction using a maximum parsimony (MP) analysis under PAUP 4.0b10 (Swofford, 2002). To determine relatedness of isolates from duku with known C. fimbriata populations, the ITS sequence was manually aligned with known ITS haplotypes as designated by Harrington et al. (2014) (Supplementary Fig. 2) and phylogenetic analyses were performed. Representative sequences of ITS haplotypes of $C$. fimbriata as designated by Harrington et al. (2014) and ITS sequences of accession numbers KF878326, KF650948, AM712445, AM292204, MF033455, EU588656, KC261853, which most closely matched with isolates from duku, were used in the analyses. C. variospora (accessions AF395683) was used as the outgroup taxon. There were 35 ITS sequences in the dataset (Table 1) and the sequences were initially aligned using MAFFTv.7 (Katoh et al., 2019) and then manually adjusted and trimmed in MEGA X (Kumar et al., 2018) (Supplementary Fig. 3). The relationships between ITS sequences of isolates from $L$. domesticum and other representative genotypes of the $C$. fimbriata sensu stricto (Harrington et al., 2014; Oliveira et al., 2015) were analysed using genetic distance matrices, unweighted pair group method with arithmetic means (UPGMA), and 1,000 bootstrap replications under PAUP 4.0b10 (Swofford, 2002).

Pathogenicity tests. Two isolates identified using DNA sequence data were used to test for pathogenicity. Pathogenicity tests were conducted on 1-year-old duku (Lansium domesticum var. domesticum) seedlings grown in a partially flooded and in a non-flooded nursery. Seedlings were grown in $20 \mathrm{~cm}$ diameter plastic pots containing a mixture of topsoil and compost under a $25 \%$ shading net. The pots from the flooded nursery were placed in a tray filled with tap water, which was maintained to a depth of 2-3 cm. Pathogenicity was also tested on 3-month-old acacia ( $A$. mangium) and 6-month-old mango (Mangifera indica cv. Arumanis) seedlings.

Preliminary tests showed that stem inoculations with a mycelial plug were ineffective unless the bark was wounded. Therefore, wound inoculation was used throughout the experiments. Wounds were made by puncturing three points on the bark to a 3-mm depth using a sterile $28 \mathrm{~g}$ needle, and a $2 \times 2 \mathrm{~mm}$ agar plug taken from an actively growing colony on $2 \%$ MEA was placed in the wound with the mycelium downward. This was covered with a section (10 $\times 10 \mathrm{~mm}$ ) of wetted tissue paper and wrapped with clear tape to reduce contamination and desiccation. The inoculum along with the wrapping plastic was removed at 3 days post-inoculation. Each isolate was injected into 10 seedlings for each flooded and non-flooded group of seedlings. For uninoculated controls, wounded bark was wrapped with sterile MEA plugs. Whole experiments were repeated twice and data were pooled after verifying the variance homogeneity using the Levene test.

Disease severity was assessed 20 days post-inoculation based on the length of wood discoloration. Sections were cut from the margins of lesions, surface-sterilized, and plated on MEA or inserted into a carrot dish to re-isolate the inoculated fungus to complete Koch's postulates. Fungal identity was verified by colony, anamorph, and teleomorph morphology. 

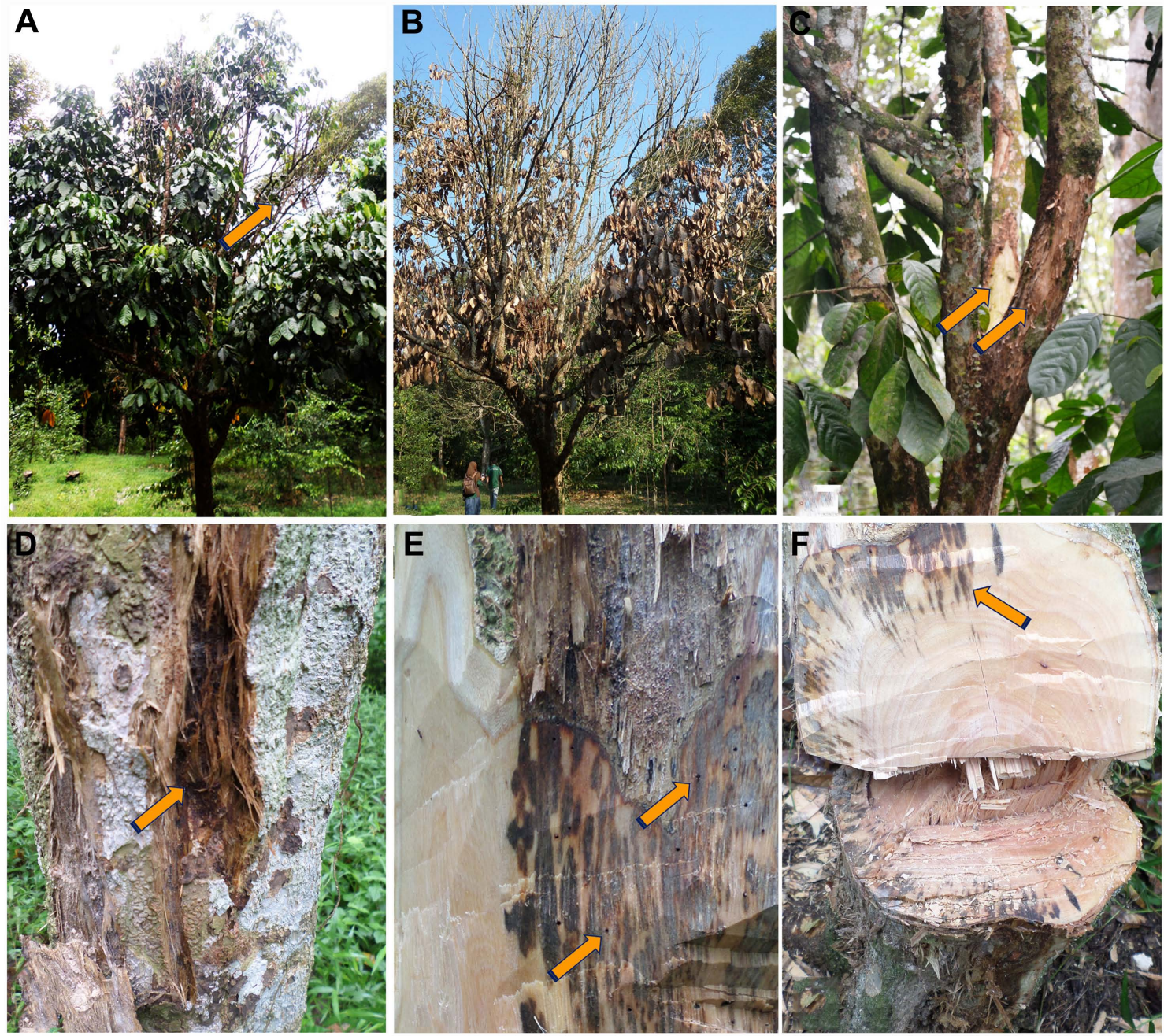

Fig. 1. Symptoms of Ceratocystis wilt on duku trees (Lansium domesticum var. domesticum). (A) Partial wilting and fast dieback of upper twigs and branches. (B) Total plant wilt and dieback after 6 months of partial wilting. (C) Peeled-off bark of branches due to squirrel attacks on diseased tree. (D) Bark canker on heavily infected trunk. (E) The discolored wood beneath the outermost layers of sapwood and a beetle entry/exit hole on affected wood. (F) The discolored wood extended to the heartwood of the basal stem. Arrows indicate the sites of described symptoms.

\section{Results}

Field observations and symptom development. Diseased trees were characterized by wilting of some twigs or branches, followed by defoliation and dieback. In most cases, total plant wilt or death was observed within 6 months from the first appearance of wilt (Fig. 1A and B). Bark canker was eventually found on heavily infected trunks or dead trees (Fig. 1D). Scraping the bark down to the wood along the wilted side of the trunk up to the branch revealed extensive areas of discolored tissue (Fig. 1E and F). The discolored wood typically had a streaked appearance, turning a uniform dark brown with age and could be found beneath the outermost layers of sapwood (Fig. 1E) and in some cases, discoloration extended to the heartwood (Fig. 1F). All diseased trees had been attacked by squirrels (Fig. 1C) and lesions appeared to originate from surrounding beetle entry/exit holes (Fig. 1E) on the peeled-off bark, indicating the involvement of a wound pathogen.

The disease was observed along the watershed of the Komering River, including Lubuk Batang (OKU District) and Rasuan (OKU Timur District), all in South Sumatra Province of Sumatra. Affected trees ranged from young $(<5$ years) to old ( $>50$ years) in age. Disease incidence and severity were highest in Lubuk Batang Lama, where the disease first appeared. The disease progress both in term of incidence and severity was fast. All trees (100\%) from 
Table 2. Incidence of Ceratocystis wilt in duku orchards of Ogan Komering Ulu District, South Sumatra

\begin{tabular}{lccc}
\hline \multirow{2}{*}{ Location (trees/location) } & \multicolumn{3}{c}{ Incidence (\%) } \\
\cline { 2 - 4 } & February 2014 & August 2014 & November 2017 \\
\hline Belatung $(n=66)$ & 36 & 86 & 100 \\
Lubuk Batang Baru $(n=85)$ & 38 & 55 & 100 \\
Lubuk Batang Lama $(n=69)$ & 63 & 100 & 100 \\
\hline
\end{tabular}

eight sampled duku orchards in OKU District of South Sumatra where the disease originated had wilted and died in the November 2017 survey (Table 2). In the 2019 field observation, the disease was found to have sporadically killed duku trees in Ogan Komering Ulu Timur (OKUT) District (within $100 \mathrm{~km}$ of the disease origin). Squirrel attacks were not found on the recently infected trees. Disease was not found in other duku orchards of South Sumatra in OKI, PALI, and Muara Enim districts. There was no appearance of squirrel scratches in those disease-free orchards.

Culture characteristics and morphology. Fungi typical of genus Ceratocystis were consistently isolated from direct plating of diseased wood on to both MEA and carrot slices.
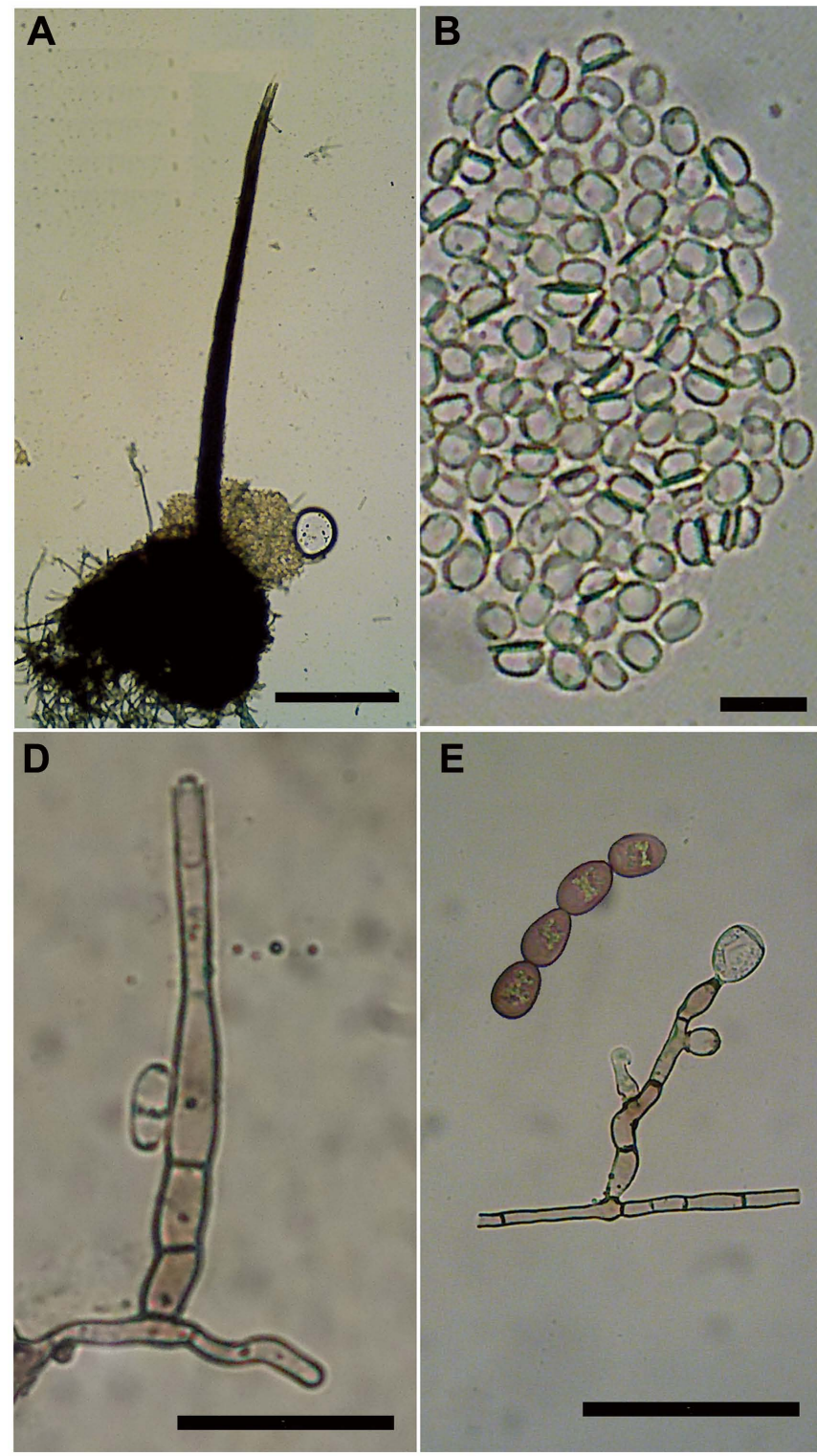

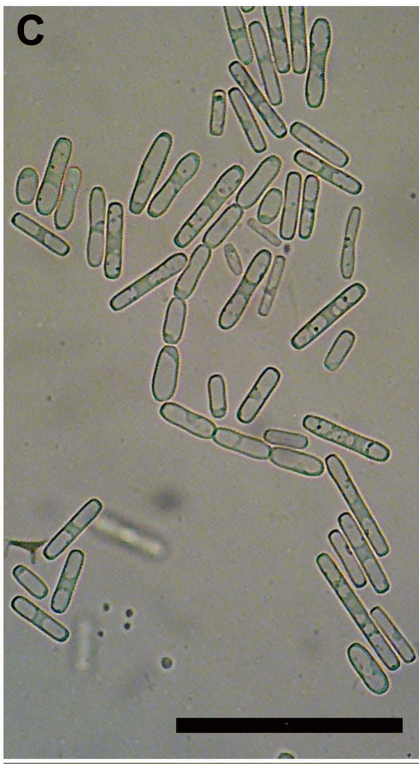

$\mathrm{F}$

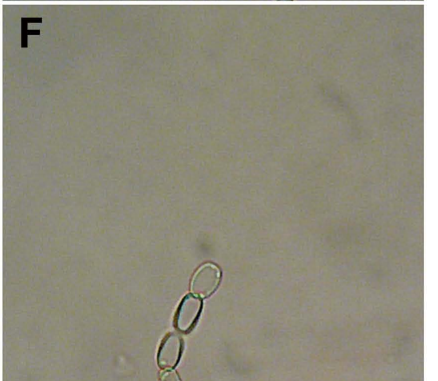

Fig. 2. Morphological characteristics of Ceratocystis fimbriata isolate WRC from bark canker of Lansium domesticum. (A) Globose ascomata with long neck. (B) Ascospores. (C) Cylindrical conidia. (D) Primary phialidic conidiophore with emerging cylindrical conidia. (E) Chlamydospore. (F) Barrelshaped conidia in chain. Scale bars $=100 \mu \mathrm{m}$ (A), $10 \mu \mathrm{m}$ (B), $50 \mu \mathrm{m}(\mathrm{C}-\mathrm{F})$. 
Colonisation of Phytophthora on diseased wood was not detected by baiting using cacao pods and cucumber fruit. Ceratocystis isolates from $L$. domesticum trees were typical of Ceratocystis spp. in the C. fimbriata sensu lato species complex, having characteristic olive-green colonies and the typical banana-fruit odour. They had globose to sub-glo- bose ascomata with long necks and typical divergent ostiolar hyphae at their tips (Fig. 2). Teleomorph and anamorph structures were produced within 2 weeks on MEA cultures. Two isolates (WRC and WBC) were described and both had ascospore $(4-7 \times 3-5 \mu \mathrm{m})$, cylindrical conidia $(14-25 \times$ 4-5 $\mu \mathrm{m})$, and aleuroconidia sizes $(11-16 \times 7-11 \mu \mathrm{m})$ within

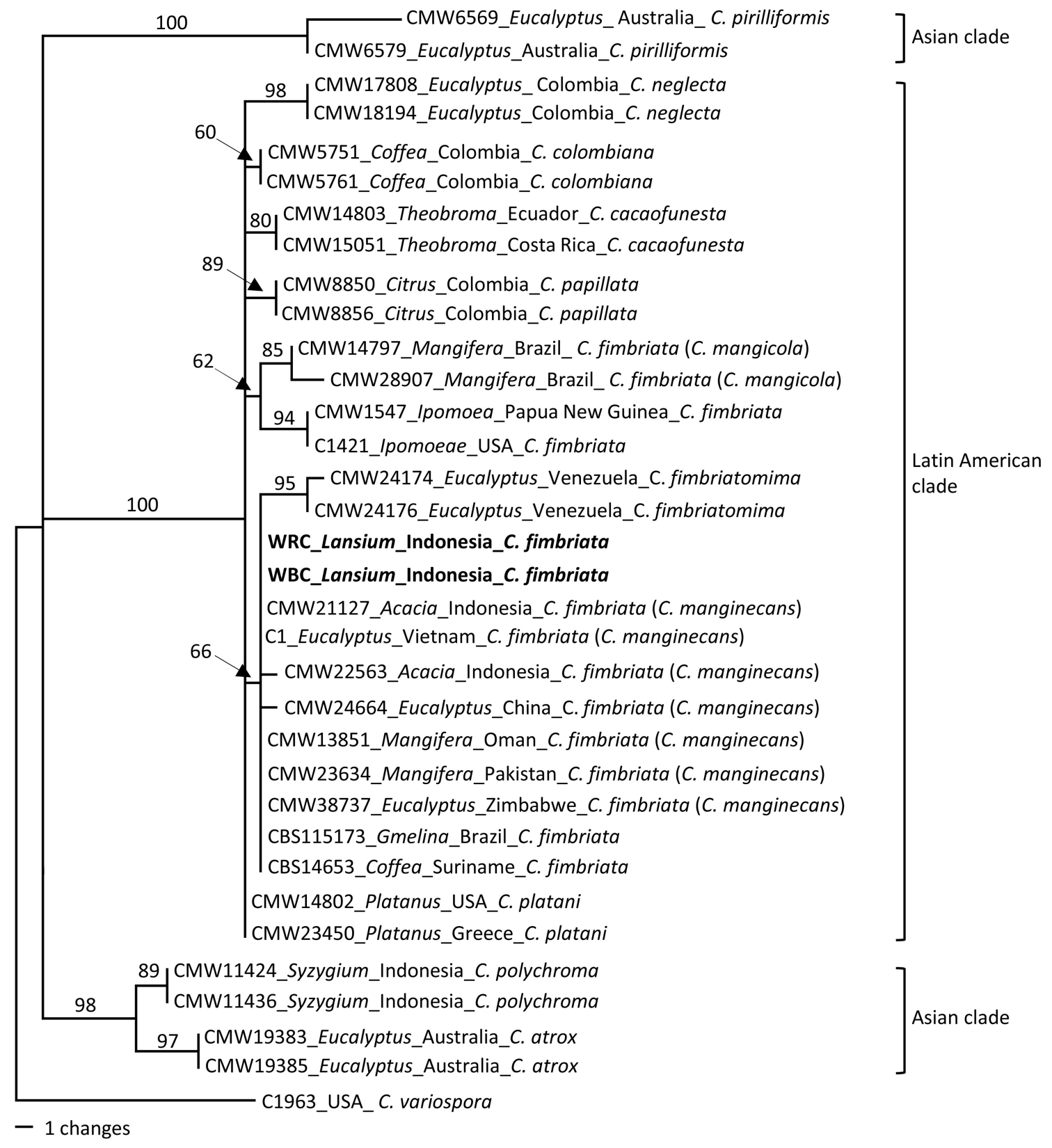

Fig. 3. Phylogenetic tree generated from maximum parsimony analysis of the $\beta$-tubulin sequences showing the relationship between Ceratocystis fimbriata from Lansium tree in Indonesia (marked in bold) and other species in the Latin American and Asian clade of the C. fimbriata species complex. The strain numbers, host genera, countries of origin, and species are given for the representatives of each isolate. Species names considered to be synonyms of $C$. fimbriata sensu stricto are in parentheses (Harrington et al., 2014; Oliveira et al., 2015). C. variospora was used as the outgroup taxon. Bootstrap values greater than $50 \%$ obtained after a bootstrap test with 1,000 replications are indicated on appropriate nodes. 
the range of those of $C$. fimbriata sensu stricto neotype BPI 595863 (Engelbrecht and Harrington, 2005). Both isolates produced a barrel-shaped (doliform) conidia $(8-10 \times 6-8$ $\mu \mathrm{m})$ in chain (Fig. 2).

Sequence analyses. WBC and WBC isolates had differences in two bases of ITS sequence (99.6\% similarity), but had a $100 \%$ similarity in the TUB sequence. BLAST searches of the ITS region of WRC (MT229127) and WBC (MT229128) identified both sequences with the GenBank deposits for $C$. fimbriata with $100 \%$ of similarity and query coverage. A similar BLAST result was obtained with the TUB sequence (MW013766 and MW013767 for WBC and WBC, respectively) and confirmed the assignment to $C$. fimbriata with $100 \%$ of similarity and query coverage.

MP analyses for the $\beta$-tubulin resulted in single most parsimonious tree of 84 steps (Fig. 3), with a homoplasy index $=0.036$, consistency index $=0.964$, rescaled consistency index $=0.979$, and retention index $=0.944$. Ceratocystis isolates from Lansium in Indonesia reside in the LAC of $C$. fimbriata sensu lato and they are phylogenetically clustered closely with ex-type and ex-paratype of $C$. manginecans and $C$. fimbriata. C. manginecans is considered synonym or conspecific of $C$. fimbriata sensu stricto (Harrington et al., 2014; Oliveira et al., 2015).

Manual alignment of the ITS sequences with previously described ITS genotypes (Harrington et al., 2014) grouped the isolates into ITS5 and ITS6z haplotype of $C$. fimbriata

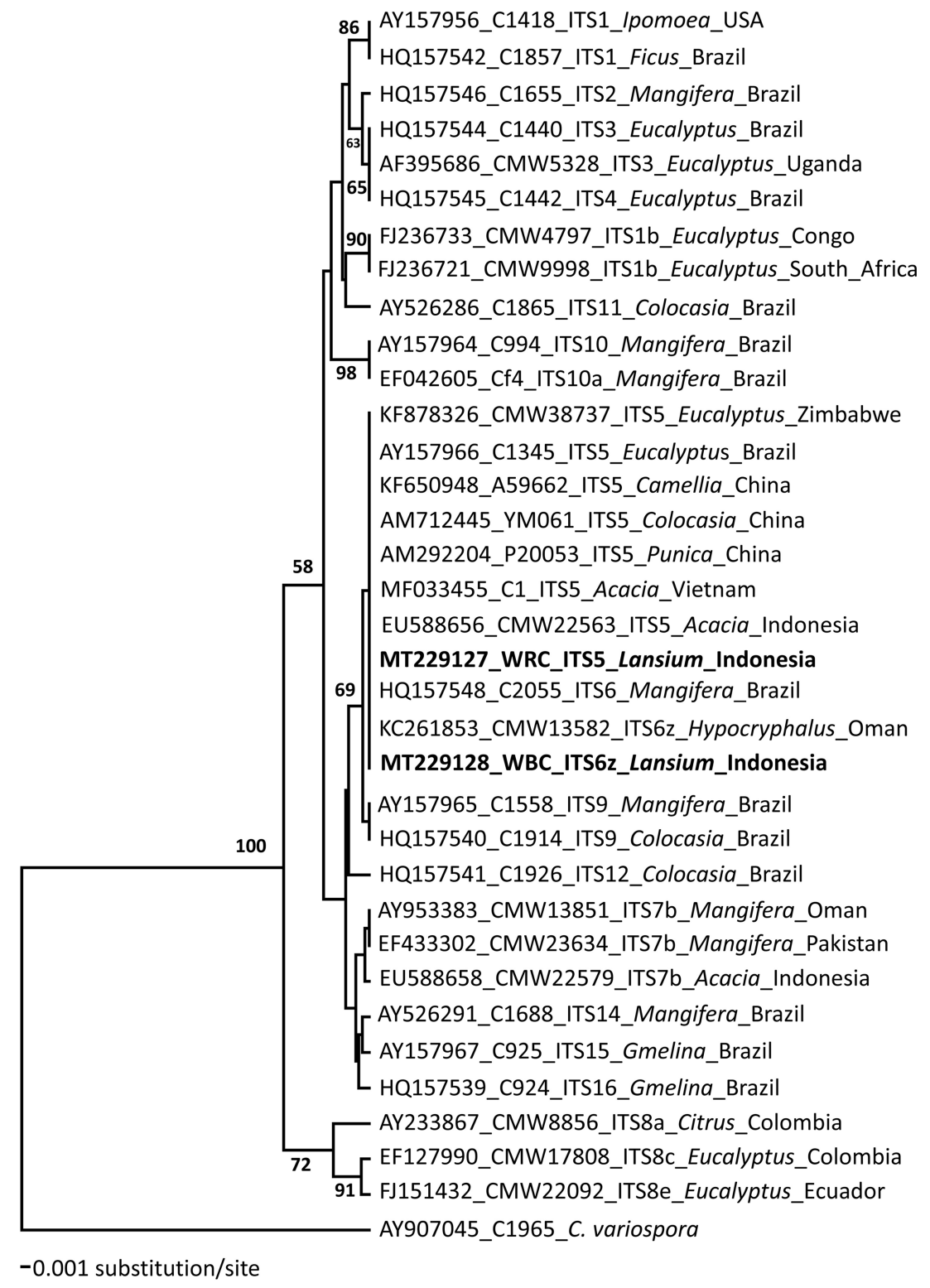

Fig. 4. Dendrogram generated by unweighted pair group method with arithmetic means showing the genetic relatedness of representative the internal transcribed spacer (ITS) rDNA genotypes (sequences) of the Ceratocystis fimbriata sensu stricto. The GenBank accession numbers, strain numbers, ITS haplotypes, host genera and countries of origin are given for the representatives of each haplotype. Isolates from Lansium domesticum in Indonesia were marked in bold. The ITS haplotypes of $C$. fimbriata are numbered following the numerical designations of Harrington et al. (2014). C. variospora was used as the outgroup taxon. Bootstrap values greater than $50 \%$ obtained after a bootstrap test with 1,000 replications are indicated on appropriate nodes. Scale bar indicates genetic distance. 
for WRC and WBC, respectively. The WRC showed 100\% similarity with other ITS5 haplotype of $C$. fimbriata isolated from tea tree (KF650948), taro (AM712445), pomegranate (AM292204) in China; from eucalyptus (KF878326) in Zimbabwe; from acacia (MF033455) in Vietnam; and from acacia (EU588656) in Indonesia. WBC had 100\% similarity with member of ITS6z haplotype of C. fimbriata isolated from Hypocryphalus mangiferae (KC261853) in Oman. UPGMA analysis clustered both isolates from $L$. domesticum within a single group consisted of both ITS5 and ITS6 haplotypes (Fig. 4).

Pathogenicity test. In pathogenicity tests, initial symptoms appeared as water-soaked brown lesions on the wound site within 3 days after inoculation. The lesions remained small at inoculation sites on bark, but scraping the bark down to the wood revealed extensive areas of discolored xylem tissue upward and downward from the inoculated site (Fig. 5A). Upward extension of xylem discoloration from the inoculation site was more extensive $(P<0.0001)$ than downward extension on duku seedling inoculated with WRC. However, no significant difference $(P \geq 0.05)$ between upward and downward discoloration extension was exhibited by WRC on acacia and mango and by WBC on all hosts (Table 3 ). This kind of discolored xylem was similar to a typical symptom of diseased trees in the field. The WRC isolate was more pathogenic on duku seedling than WBC as it induced significantly $(P<0.05)$ longer lesions and caused more $(P<0.05)$ plant wilt and death (Fig. 5A). Plant wilt and death was observed within 20 days postinoculation and later the wilting incidence gradually increased. Regrowth of lateral shoots was observed on wilted plants. The control plants, inoculated with MEA, remained asymptomatic and had only a trace of xylem discolouration (less than $5 \mathrm{~mm}$ in length) at the wound site (Table 3 ). Partial flooding of duku seedling did not significantly $(P$ $=0.163)$ affect extension of the xylem discoloration, but plant mortality by WRC was lower $(P<0.05)$ than on nonflooded seedling (Table 3). Fungus with the same morphological characteristics was re-isolated from diseased wood

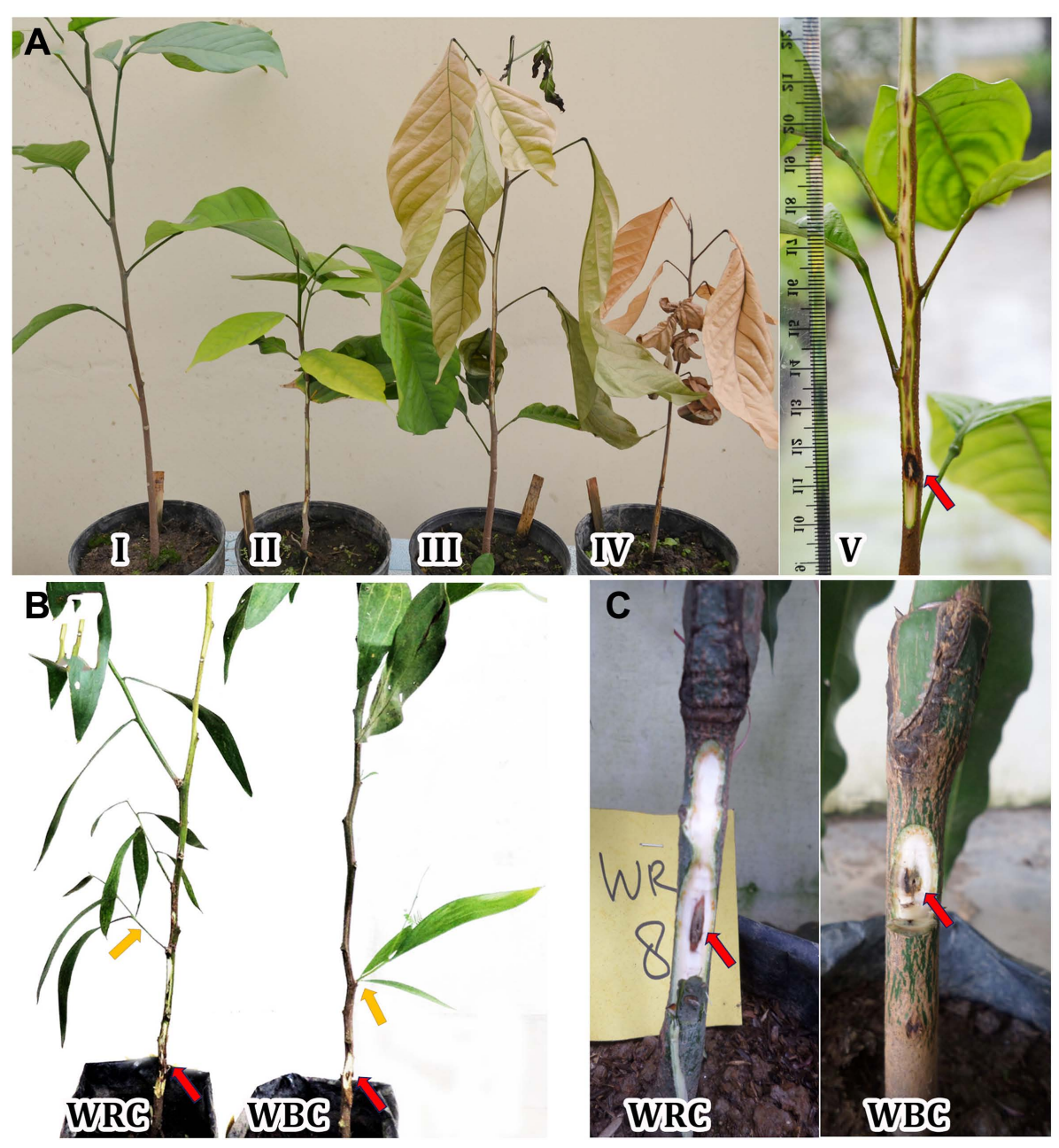

Fig. 5. Symptoms reproduced from mycelial plug inoculation with Ceratocystis fimbriata isolates (WRC and WBC) from Lansium domesticum 20 days after inoculation. (A) Symptoms on 1-yearold duku seedlings (L. domesticum) inoculated with malt extract agar plug (control) (I), restricted wood discoloration and non-wilted plant inoculated with WBC (II), partial and total wilting of plant inoculated with WRC (III, IV), upward extensive wood discoloration from inoculated site (red arrow) (V). (B) Symptoms on 3-month-old seedlings of Acacia mangium showing extensive wood discoloration by WRC and limited lesions by WBC. Yellow arrows indicate new lateral shoot growth on diseased Acacia and red arrows indicate point of inoculation. (C) Symptoms on 6-month-old seedlings of Mangifera indica cv. Arumanis showing wood discoloration at site of inoculation (red arrows). 
Table 3. Pathogenicity of Ceratocystis fimbriata isolates on 1-year-old duku (Lansium domesticum var. domesticum), 3-month-old Acacia mangium, and 6-month-old Mangifera indica cv. Arumanis seedlings

\begin{tabular}{|c|c|c|c|c|c|c|}
\hline \multirow{2}{*}{ Isolate and plant species } & \multirow{2}{*}{ Flooding stress } & \multicolumn{3}{|c|}{ Length $(\mathrm{mm})$ of wood discoloration ${ }^{\mathrm{a}}$} & \multirow{2}{*}{$\begin{array}{l}\text { Wilting and } \\
\text { death at } 20 \mathrm{dpi}\end{array}$} & \multirow{2}{*}{$\begin{array}{l}\text { Wilting and } \\
\text { death at } 60 \mathrm{dpi}\end{array}$} \\
\hline & & Downward & Upward & Total & & \\
\hline \multicolumn{7}{|l|}{ Lansium domesticum } \\
\hline \multirow[t]{2}{*}{ WRC } & Partial flooding & $11.3 \pm 1.7^{*}$ & $22.8 \pm 6.1$ & $34.1 \pm 6.4 \mathrm{ab}$ & $1 / 20$ & $7 / 20 b$ \\
\hline & Without flooding & $12.6 \pm 1.9 *$ & $37.3 \pm 11.1$ & $49.9 \pm 11.4 \mathrm{a}$ & $5 / 20$ & $15 / 20 \mathrm{a}$ \\
\hline \multirow[t]{2}{*}{ WBC } & Partial flooding & $6.2 \pm 0.8$ & $9.6 \pm 3.3$ & $15.8 \pm 3.4 \mathrm{bc}$ & $0 / 20$ & $0 / 20 \mathrm{c}$ \\
\hline & Without flooding & $5.0 \pm 0.5$ & $5.6 \pm 0.8$ & $10.6 \pm 1.3 \mathrm{c}$ & $0 / 20$ & $2 / 20 b c$ \\
\hline \multirow[t]{2}{*}{ MEA (control) } & Partial flooding & $1.9 \pm 0.1$ & $2.0 \pm 0.1$ & $3.9 \pm 0.2 \mathrm{~d}$ & $0 / 20$ & $0 / 20 \mathrm{c}$ \\
\hline & Without flooding & $1.9 \pm 0.2$ & $1.9 \pm 0.1$ & $3.8 \pm 0.3 \mathrm{~d}$ & $0 / 20$ & $0 / 20 c$ \\
\hline \multicolumn{7}{|l|}{ Acacia mangium } \\
\hline WRC & Without flooding & $42.1 \pm 3.5$ & $34.9 \pm 7.3$ & $76.9 \pm 14.8 \mathrm{a}$ & $6 / 20$ & $17 / 20 \mathrm{a}$ \\
\hline WBC & Without flooding & $17.8 \pm 4.1$ & $18.0 \pm 8.4$ & $35.8 \pm 6.3 b$ & $1 / 20$ & $5 / 20 b$ \\
\hline MEA (control) & Without flooding & $2.1 \pm 0.2$ & $2.1 \pm 0.2$ & $4.1 \pm 0.4 \mathrm{c}$ & $0 / 20$ & $0 / 20 \mathrm{c}$ \\
\hline \multicolumn{7}{|c|}{ Mangifera indica $\mathrm{cv}$. Arumanis } \\
\hline WRC & Without flooding & $5.1 \pm 1.0$ & $5.6 \pm 0.9$ & $9.7 \pm 1.7 \mathrm{a}$ & $0 / 20$ & $0 / 20$ \\
\hline WBC & Without flooding & $7.1 \pm 1.3$ & $7.3 \pm 1.1$ & $14.4 \pm 1.7 \mathrm{a}$ & $0 / 20$ & $0 / 20$ \\
\hline MEA (control) & Without flooding & $1.3 \pm 0.1$ & $1.3 \pm 0.1$ & $2.6 \pm 0.1 \mathrm{~b}$ & $0 / 20$ & $0 / 20$ \\
\hline
\end{tabular}

MEA, malt extract agar.

${ }^{a}$ Wood discoloration was measured 20 days post-inoculation (dpi). Means of downward lesion length labelled with asterisks are significantly different from upward lesion according to the Welch two sample $t$-test. Means of total lesion length by different plant species followed by common letter are not significantly different according to the honestly significant difference test.

${ }^{b}$ Number of death plants by different plant species labelled by same letter are not significantly different according to the Fisher's exact test of independence with applying the Bonferroni corrected alpha level.

of inoculated seedlings, but not from any of the control plants.

Ceratocystis isolates also induced xylem discolouration and wilt symptoms on inoculated A. mangium seedlings (Fig. 5B), similar to that observed on duku seedlings. Xylem discoloration on acacia developed faster than on duku and was equally extensive $(P \geq 0.05)$ for both upward and downward expansion (Table 3). Plant wilt and death was observed earlier on acacia compared to duku with half the WRC-inoculated acacia dying within 20 days post-inoculation. Similar to what was observed on duku seedlings, the WRC isolate caused significantly $(P<0.05)$ longer lesion and more death on acacia and therefore, proved to be more pathogenic than WBC (Table 3). Ceratocystis isolates were also pathogenic on mango ( $M$. indica), but did not induce wilting symptoms (Fig. 5C). Mycelial plug inoculation on stems of mango resulted in wood discoloration similar to the symptoms on duku and acacia (Fig. 5C), but with less expansive discoloration (Table 3).

\section{Discussion}

This study presents the first report of $C$. fimbriata associated with massive mortality of $L$. domesticum trees in
South Sumatra, Indonesia. This fungus was shown to be pathogenic by producing expansive wood discoloration and causing lethal wilt on inoculated duku seedlings similar to that found in the field. Fungus with the same morphological characteristics was easily re-isolated from diseased wood of inoculated seedlings, suggesting fulfilment of Koch's postulates. Inoculation experiments on acacia seedlings suggested that the pathogen was also pathogenic there by producing more expansive wood discoloration, bark canker, wilting symptoms, and plant death. Ceratocystis isolates from duku proved to be less pathogenic on mango, as less wood discoloration was induced, without wilting and plant death.

The ITS rDNA sequence of the most pathogenic isolate, WRC (MT229127), had an identical sequence to the isolates of $C$. fimbriata from tea tree (KF650948), taro (AM712445), and pomegranate (AM292204) in China; from eucalyptus (KF878326) from Zimbabwe; from acacia (MF033455) in Vietnam; and from acacia (EU588656) in Indonesia. All these isolates were confirmed belong to ITS5 haplotype of $C$. fimbriata (Harrington et al., 2014; Li et al., 2016). Some of these isolates were previously identified as C. acaciivora (Tarigan et al., 2011) and subsequently reconsidered as $C$. manginecans (Fourie et al., 2015), but 
Oliveira et al., (2015) considered those cryptic species to be synonyms or conspecifics of $C$. fimbriata sensu stricto. The ITS5 haplotype is an aggressive genotype of $C$. fimbriata causing a lethal wilt disease of economically important plants worldwide. This genotype represented the native C. fimbriata populations in Brazilian forest plantations of Eucalyptus spp. (Harrington et al., 2014, 2015; Li et al., 2016). This ITS haplotype was also found infecting Acacia spp. and its original host, Eucalyptus spp. in China, Indonesia, South Africa, Thailand, Uruguay (Harrington et al., 2014), Zimbabwe (Jimu et al., 2015) and Vietnam (Trang et al., 2018). The member of this Eucalyptus population of $C$. fimbriata cause the wilt epidemic on kiwifruit in Brazil (Ferreira et al., 2017). In China, the ITS5 genotype has been considered to be introduced from Brazil through Eucalyptus cuttings and reported to cause epidemics on pomegranate, loquat, and taro (Harrington et al., 2015; Li et al., 2016), and tea tree (Xu et al., 2019).

The less pathogenic isolate, WBC, is grouped as ITS6z, a minor haplotype derived from a single haploid strain of C2759 (CBS 135868). The C2759 was originated from Dalbergia sissoo in Pakistan and its single-ascospore culture yielded many different haplotypes with the ITS7b as the major genotype (Harrington et al., 2014). WBC had $100 \%$ similarity with other member of ITS6z haplotype (type $\mathrm{Y}=\mathrm{KC} 261853$ ) of $C$. fimbriata isolate CMW13582 originated from the bark beetle, $H$. mangiferae in Oman (Naidoo et al., 2013). The ITS7b is a common ITS genotype of $C$. fimbriata from Oman, Pakistan, and Indonesia that previously described as $C$. manginecans (Harrington et al., 2014; Oliveira et al., 2015). Many isolates in Asia and Oman have mixed ITS sequences due to crosses between the ITS5, ITS6, and ITS7b genotypes (Oliveira et al., 2015). In this study, Ceratocystis isolates from Indonesia (ITS5 and ITS6z) and members of ITS7b haplotype (CMW13851 and CMW23634 from Oman and Pakistan, respectively) are grouped into a single phylogenetic cluster of $C$. fimbriata sensu stricto based on partial $\beta$-tubulin sequence. It is likely that the population of $C$. fimbriata causing disease on duku and acacia in Sumatra is a combination of ITS5, ITS6, and ITS7b, with the ITS6z a result of crossing of these haplotypes. Morphological characteristics showed that the pathogen belonged to the species C. fimbriata (Engelbrecht and Harrington, 2005). Both Ceratocystis isolates from duku (WRC and WBC) had a similar morphology to $C$. fimbriata sensu stricto neotype BPI 595863 (Engelbrecht and Harrington, 2005), except for doliform conidia that were absent on BPI 595863. Phylogenetic analyses based on the ITS and $\beta$-tubulin regions showed conclusively that Ceratocystis isolates causing bark canker and lethal wilt on duku tree in Indonesia is identified as $C$. fimbriata sensu stricto. There were two ITS genotypes of $C$. fimbriata associated with disease on Lansium tree in Indonesia, one consistent with that found in Oman and Pakistan on the mango bark beetle and Dalbergia (and other hosts) and a second sequence found in China, Indonesia, Vietnam and Brazil on various hosts, including acacia. C. fimbriata has been known to infect a wide variety of annual and perennial host plants throughout the world. In Indonesia, diseases caused by $C$. fimbriata are considered to be of minor importance due to non-lethal and sporadic infestation. The fungal infection has long been noted to cause a non-lethal disease known as mouldy rot on the trunk of rubber trees (Tayler and Stephens, 1929). The role of fungal infection as the primary causal agent of the disease has been dismissed since mouldy rot is considered an advanced stage of a physiological disorder induced by excessive tapping and ethylene overstimulation (Putranto et al., 2015) and the disease can be eliminated by treatment with non-fungicidal biostimulants (Suwandi et al., 2018). In the last decade, disease incited by $C$. fimbriata has been one of the most destructive and economically important diseases on acacia plantations in Indonesia, shortly after an outbreak on the industrial forest plantations throughout the world (Roux and Wingfield, 2009). Outbreaks of Ceratocystis disease have forced the replacement of thousands of hectares of $A$. mangium plantations in eastern Sabah, Malaysia (Brawner et al., 2015). In Indonesia, Ceratocystis infection has contributed to $2 \%$ mortality by the fourth rotation of A. mangium in Sumatra, Indonesia (Hardie et al., 2018). Pathogens causing lethal wilt of duku belong to ITS haplotype 5, which represented $C$. fimbriata populations from forest plantations of Acacia spp. and Eucalyptus spp. Pathogenicity tests also confirmed that $A$. mangium is more susceptible than the original host (duku tree), suggesting the establishment of $C$. fimbriata pathogenicity on acacia as the main host. Similar disease symptoms caused by Ceratocystis infections were found to be endemic on acacia and eucalyptus plantations located about $30 \mathrm{~km}$ away from the site of study. It is likely that population of $C$. fimbriata pathogenic on acacia plantation could extend their host range to native fruit tree such as Lansium and cause a serious threat to the neighbouring fruit tree species. The hostrange extension by the ITS5 haplotype of $C$. fimbriata to the susceptible neighbouring plants occurred in Brazil, in which the genotype from eucalyptus showed strong aggressiveness on taro (Harrington et al., 2011) and caused epidemic on grapevine (Ferreira et al., 2017). Similar host extension by the ITS5 haplotype also occurred in China, in which the eucalyptus population caused epidemic on 
pomegranate, loquat, and taro (Harrington et al., 2015; Li et al., 2016), and tea tree (Xu et al., 2019).

All sampled diseased trees had been previously attacked by squirrels and lesions appeared to originate from surrounding beetle entry/exit holes on peeled-off bark from squirrel scratches, suggesting the involvement of the wild vertebrate as the wound creator and beetles for fungal spore dispersion. Fungal feeding insects, such as $H$. mangiferae, have been suggested to be associated with the rapid distribution of $C$. fimbriata in Oman and Pakistan (Al Adawi et al., 2013). Squirrel attacks on either diseased or healthy duku trees were found only during the disease outbreaks in 2013-2014 and these attacks were likely due to the limitation of squirrel feed sources in the field. All affected orchards had grown duku in a monoculture. Pathogenicity tests supported the idea that partial flooding was not likely to predispose duku trees to Ceratocystis infection as the disease did not develop well under partial flooding. Recent field observations in areas near the disease origin suggested that the disease spreads sporadically with limited mortality. Squirrel attacks were not found on recently infected trees, suggesting the possible involvement of the wild vertebrate wounds on the massive disease spread in duku orchards. Vertebrate-incited wounds, such as those from squirrels and monkeys, are considered to contribute to the spread of Ceratocystis wilt on A. mangium plantations (Brawner et al. 2015; Hardie et al. 2018; Nasution et al., 2019).

\section{Conflicts of Interest}

No potential conflict of interest relevant to this article was reported.

\section{Acknowledgments}

We thank the editors and reviewers for critical review of the manuscript. This research was supported by the Sriwijaya University Priority Applied Research Project 023/ SP2H/LT/DPRM/II/2016.

\section{Electronic Supplementary Material}

Supplementary materials are available at The Plant Pathology Journal website (http://www.ppjonline.org/).

\section{References}

Al Adawi, A. O., Al Jabri, R. M., Deadman, M. L., Barnes, I., Wingfield, B. and Wingfield, M. J. 2013. The mango sudden decline pathogen, Ceratocystis manginecans, is vectored by Hypocryphalus mangiferae (Coleoptera: Scolytinae) in Oman. Eur. J. Plant Pathol. 135:243-251.

Badan Pusat Statistik-Statistics Indonesia. 2018. Statistics of annual fruit and vegetable plants Indonesia 2017. URL https:// www.bps.go.id/publication/2018/10/05/081665ec9eb65fd ce8a69473/statistik-tanaman-buah---buahan-dan-sayurantahunan-indonesia-2017 [17 March 2020].

Barnes, I., Fourie, A., Wingfield, M. J., Harrington, T. C., McNew, D. L., Sugiyama, L. S., Luiz, B. C., Heller, W. P. and Keith, L. M. 2018. New Ceratocystis species associated with rapid death of Metrosideros polymorpha in Hawai'i. Persoonia 40:154-181.

Brawner, J., Japarudin, Y., Lapammu, M., Rauf, R., Boden, D. and Wingfield, M. J. 2015. Evaluating the inheritance of Ceratocystis acaciivora symptom expression in a diverse Acacia mangium breeding population. South. For. 77:83-90.

Brito, R. A. S., Cavalcante, G. P., Borel, F. C. and Maffia, L. A. 2019. Detection and isolation of Ceratocystis fimbriata in mango trees on semi-selective medium. Eur. J. Plant Pathol. 155:667-669.

Chen, S., Van Wyk, M., Roux, J., Wingfield, M. J., Xie, Y. and Zhou, X. 2013. Taxonomy and pathogenicity of Ceratocystis species on Eucalyptus trees in South China, including C. chinaeucensis sp. nov. Fungal Divers. 58:267-279.

Engelbrecht, C. J. B. and Harrington, T. C. 2005. Intersterility, morphology and taxonomy of Ceratocystis fimbriata on sweet potato, cacao and sycamore. Mycologia 97:57-69.

Ferreira, M. A., Harrington, T. C., Piveta, G. and Alfenas, A. C. 2017. Genetic variability suggests that three populations of Ceratocystis fimbriata are responsible for the Ceratocystis wilt epidemic on kiwifruit in Brazil. Trop. Plant Pathol. 42:86-95.

Fourie, A., Wingfield, M. J., Wingfield, B. D. and Barnes, I. 2015. Molecular markers delimit cryptic species in Ceratocystis sensu stricto. Mycol. Prog. 14:1020.

Glass, N. L. and Donaldson, G. C. 1995. Development of primer sets designed for use with the PCR to amplify conserved genes from filamentous ascomycetes. Appl. Environ. Microbiol. 61:1323-1330.

Hardie, M., Akhmad, N., Mohammed, C., Mendham, D., Corkrey, R., Gafur, A. and Siregar, S. 2018. Role of site in the mortality and production of Acacia mangium plantations in Indonesia. South. For. 80:37-50.

Harrington, T. C., Huang, Q., Ferreira, M. A. and Alfenas, A. C. 2015. Genetic analyses trace the Yunnan, China population of Ceratocystis fimbriata on pomegranate and taro to populations on Eucalyptus in Brazil. Plant Dis. 99:106-111.

Harrington, T. C., Kazmi, M. R., Al-Sadi, A. M. and Ismail, S. I. 2014. Intraspecific and intragenomic variability of ITS rDNA sequences reveals taxonomic problems in Ceratocystis fimbriata sensu stricto. Mycologia 106:224-242.

Harrington, T. C., Thorpe, D. J. and Alfenas, A. C. 2011. Genetic variation and variation in aggressiveness to native and exotic hosts among Brazilian populations of Ceratocystis fimbriata. 
Phytopathology 101:555-566.

Jimu, L., Wingfield, M. J., Mwenje, E. and Roux, J. 2015. Diseases on Eucalyptus species in Zimbabwean plantations and woodlots. South. For. 77: 221-230.

Katoh, K., Rozewicki, J. and Yamada, K. D. 2019. MAFFT online service: multiple sequence alignment, interactive sequence choice and visualization. Brief. Bioinform. 20:11601166.

Keith, L. M., Matsumoto, T. K. and McQuate, G. T. 2013. First report of Dolabra nepheliae associated with corky bark disease of langsat in Hawaii. Plant Dis. 97:990.

Kumar, S., Stecher, G., Li, M., Knyaz, C. and Tamura, K. 2018. MEGA X: molecular evolutionary genetics analysis across computing platforms. Mol. Biol. Evol. 35:1547-1549.

Li, Q., Harrington, T. C., McNew, D., Li, J., Huang, Q., Somasekhara, Y. M. and Alfenas, A. C. 2016. Genetic bottlenecks for two populations of Ceratocystis fimbriata on sweet potato and pomegranate in China. Plant Dis. 100:2266-2274.

Luchi, N., Ghelardini, L., Belbahri, L., Quartier, M. and Santini, A. 2013. Rapid detection of Ceratocystis platani inoculum by quantitative real-time PCR assay. Appl. Environ. Microbiol. 79:5394-5404.

Moller, W. J. and DeVay, J. E. 1968. Carrot as a species-selective isolation medium for Ceratocystis fimbriata. Phytopathology 58:123-124.

Naidoo, K., Steenkamp, E. T., Coetzee, M. P., Wingfield, M. J. and Wingfield, B. D. 2013. Concerted evolution in the ribosomal RNA cistron. PLoS ONE 8:e59355.

Nasution, A., Glen, M., Beadle, C. and Mohammed, C. 2019. Ceratocystis wilt and canker: a disease that compromises the growing of commercial Acacia-based plantations in the tropics. Aust. For. 82:80-93.

Oliveira, L. S. S., Harrington, T. C., Ferreira, M. A., Damacena, M. B., Al-Sadi, A. M., Al-Mahmooli, I. H. S. and Alfenas, A. C. 2015. Species or genotypes? Reassessment of four recently described species of the Ceratocystis wilt pathogen, Ceratocystis fimbriata, on Mangifera indica. Phytopathology 105:1229-1244.

Putranto, R.-A., Herlinawati, E., Rio, M., Leclercq, J., Piyatrakul, P., Gohet, E., Sanier, C., Oktavia, F., Pirrello, J., Kuswanhadi and Montoro, P. 2015. Involvement of ethylene in the latex metabolism and tapping panel dryness of Hevea brasiliensis. Int. J. Mol. Sci. 16:17885-17908.

Roux, J. and Wingfield, M. J. 2009. Ceratocystis species: emerging pathogens of non-native plantation Eucalyptus and Acacia species. South. For. 71:115-120.

Suwandi, S., Junita, A., Suparman, S., Umayah, A., Hamidson, H., Muslim, A. and Irsan, C. 2018. Curative activity of watery fermented compost extract as a bark treatment against tapping panel dryness. Open Agric. J. 12:74-83.

Swofford, D. L. 2002. PAUP*: phylogenetic analysis using parsimony (*and other methods), version 4.0b10. Sinauer Associates, Sunderland, MA, USA.

Tarigan, M., Roux, J., van Wyk, M., Tjahjono, B. and Wingfield, M. J. 2011. A new wilt and die-back disease of Acacia mangium associated with Ceratocystis manginecans and C. acaciivora sp. nov. in Indonesia S. Afr. J. Bot. 77:292-304.

Tayler, V. A. and Stephens, J. 1929. Native rubber in the Dutch East Indies: report to the Rubber Growers' Association. Rubber Growers Association, London, UK. 48 pp.

Techavuthiporn, C. 2018. Langsat - Lansium domesticum. In: Exotic fruits reference guide, eds. by S. Rodrigues, E. de Oliveira Silva and E. S. de Brito, pp. 279-283. Academic Press, New York, USA.

Trang, T. T., Eyles, A., Davies, N., Glen, M., Ratkowsky, D. and Mohammed, C. 2018. Screening for host responses in Acacia to a canker and wilt pathogen, Ceratocystis manginecans. For. Pathol. 48:e12390.

van Wyk, M., Al Adawi, A. O., Khan, I. A., Deadman, M. L., Al Jahwari, A. A., Wingfield, B. D., Ploetz, R. and Wingfield, M. J. 2007. Ceratocystis manginecans sp. nov., causal agent of a destructive mango wilt disease in Oman and Pakistan. Fungal Divers. 27:213-230.

Van Wyk, M., Al-Adawi, A. O., Wingfield, B. D., Al-Subhi, A. M., Deadman, M. L. and Wingfield, M. J. 2005. DNA based characterization of Ceratocystis fimbriata isolates associated with mango decline in Oman. Australas. Plant Pathol. 34:587590.

Van Wyk, M., Wingfield, B. D., Marin, M. and Wingfield, M. J. 2010. New Ceratocystis species infecting coffee, cacao, citrus and native trees in Colombia. Fungal Divers. 40:103-117.

White, T. J., Bruns, T., Lee, S. and Taylor, J. 1990. Amplification and direct sequencing of fungal ribosomal RNA genes for phylogenetics. In: PCR protocols: a guide to methods and applications, eds. by M. A. Innis, D. H. Gelfand, J. J. Sninsky and T. J. White, pp. 315-322. Academic Press, San Diego, CA, USA.

Whitman, W. F. 1980. Growing and fruiting the langsat in Florida. Proc. Fla. State Hortic. Soc. 93:136-140.

Xu, K. C., Zhang, R. Q., Li, J., Bai, Y. H., Yang, X. D., Sun, Y. X. and Huang, Q. 2019. Camellia sinensis, a new host plant of Ceratocystis fimbriata from China. Plant Dis. 103:2670.

Yaacob, O. and Bamroongrugsa, N. 1991. Lansium domesticum Correa. In: Plant resources of South-East Asia. No. 2. Edible fruits and nuts, eds. by E. Westphal, P. C. M. Jansen, E. W. M. Verheij and R. E. Coronel, pp. 186-190. Pudoc, Wageningen, The Netherlands. 